\title{
Text Reduction: Strategies Adopted in Audio Visual Subtitle Translation
}

\author{
Antonius Suratno, Soegijapranata Catholic University \\ Devina Christine Wijaya, Soegijapranata Catholic University
}

\begin{abstract}
AVT (Audio Visual Translation), is one of the translation activities involving transfer of spoken and audial messages from the source text (ST) into written target texts (TT) to get displayed on digital screens. It is considered challenging because subtitle translation is constrained by the speed of spoken messages and the rolling of the digital screens. As a result, the translation work is bound to be limited in both number of characters and screen space in order to provide coherently reader-friendly texts. The constraints, consequently, compel the translators to use certain methods of translation called text reduction generally done through elimination, rendering, and condensation. This study is an attempt to find out what strategies are deployed in the subtitle translation process. Interview was also conducted to obtain first-hand information as regard the translator's reasons for using the strategies. The result shows that text reduction manifests in elimination, rendering, and condensation strategies as a part of constraint compliance. While interview result generally invigorates the above result, there is a striking finding that translators were also compelled to conform to the standard quality of the subtitles publishing company.
\end{abstract}

Keywords: translation strategies; subtitle translation; digital screen; text reduction

\section{Introduction}

Digital media is one of the new venues onto which the work of translation, generally called subtitling work, is growing as through audio visual media such a kind of work is relevantly displayed. In the multimodal world where digital media gain more and more popularity and acceptance, subtitling work lies in the among frontline of digital publishing, in particular where transfer from one to another language is required, such as on the movies, soap opera, or documentaries. The provision of subtitle is significantly facilitative to prospective wider audience in coping with language barriers as the viewing activities are undergoing. Classical written to written text translation has passed through long historical traces, but this new digitally related-mode of translation has only started to be introduced quite recently. In spite of its being very recent in its existence, this mode of translation has grown rapidly and swiftly gained its significance (Matielo, 2011, p.27), with the 1990s being considered as its golden age.

Hosseinnia (2014, Luyken, 1991: 112), defines multimedia translation, or more popularly dubbed audio-visual translation as translating spoken texts which are commonly used in radio or television programmes, movies, DVDs, videos, also operas and theatres from a source language to a target language. Chiaro (2009: 141), more specifically refers to subtitling as a written translation, the result of which is generally displayed on digital screens such as television, mobiles gadgets, computer screen, and cinematic screens. In a more refined sense, Chiaro (2007) citing Gottlieb (2001b: 87), subtitling is translating spoken messages in media into moving written texts presented on the screen. Subtitle is considered helpful and significant as it mediates viewers to understand the actors and actresses conversing even if they have to converse in the language different from that of the viewers.

The processing of this new mode of translation, however, very often poses obvious challenges as time constraint compels viewers to read and understand the whole words conversed by the actors in the blink of an eye as soon as the scenes roll onto the subsequent screens. Such a constraint has serious ramification in the part of the translators to produce a translation product which does not only have to be sound in terms of meanings but also brief and efficient in order not exceed the provided space and the screen transition pace. This means that the subtitle translators will have to adhere to the rigid spatial and temporal constraints while 
doing Interlingua translation despite being confronted by a relatively higher degree of complication and challenges byLuyken et al. (1991, in Hosseinnia, 2014).

To cope with the constraints, AV translators should effectively translate the source text (ST) into the target text (TT) as well as ingeniously choose suitable words and sentences to assure that the subtitles are the same or shorter than the audio length or visual speed. Keeping the subtitles short has a lot to do with the text reduction. Antonini (2005: 213) once said that the written text reduces $40 \%$ up to $75 \%$ from the verbal text. By so doing, the movie viewers will, in a pleasant and enjoyable momentum, read, process, then understand messages that the actors are conversing about.

The researcher sees this issue to be intriguing and worth investigating as there have been only a few researchers study the dynamic of text reduction in AV translation, especially subtitling. Matielo (2011), in his paper "Subtitling Words or Omitting Worlds? Systemic Functional Linguistics Unveiling Meanings Translated Out of the Subtitles of the TV Series Heroes" explores the issue of omissions which occur in the TV Series Heroes subtitle conforming Kovačič's findings. He, then, finds the frequent occurrence of omission to help synchronize subtitle with the movie scenes.

This research discusses the text reduction in the subtitles of an American comedy movie, Dirty Grandpa (Mazer, 2016) and an animation comedy movie Inside Out (Docter \& Carmen, 2015a). The analysis uses a theoretical framework proposed by Antonini (2005) elimination, rendering, and condensation, and the results of which are expected to be a precious input to anyone having interest in AV translation to acknowledge the importance of the strategies in the process of the AV subtitle translation.

\section{Theoretical Framework}

\section{1 Text reduction}

The act of subtitling cannot be done in a complete and faithful translation (Cintaz \& Remael, 2014: 144). Even standing firm on the "complete transcription" is considered to be impossible (Hosseinnia, 2014: 134) and is obviously not do-able. With no intention of producing low quality translation, text reduction is needed to overcome the spatial and temporal limitation. Text reduction does not deal with the loss of all the features of speech, but it rather tends to eliminate grammar and lexical items such as presented in "word order, incomplete sentences, and rhetorical questions" (Chiaro, 2007: 63). The elimination is simply done based on context-dependence. Further to it, Cintaz \& Remael (2014: 144) explain the reason for text reduction as follows:

1. Viewers need enough time to register, process, and understand what is written in the subtitle. It happens since reading written text takes more time than listening to speeches.

2. While reading the moving subtitle, viewers also need to both listen to the sound (Matielo, 2011: 28-29) and watch the visualization of what actors are doing. Again, sufficient time is needed before the speeches change.

3. Viewers have the limitation of maximum two-line subtitles.

With that in mind, it is conspicuous that text reduction is a must-do and unavoidable. Text reduction occurs through three principal strategies, i.e. rendering, and condensation (Antonini, 2005: 213-214). As Matielo (2011) once argues that there might be either one or more than one text reduction strategies in a sentence. Also, the extent of word omissions is varied. The necessity of word omissions might be due to the reason for effectiveness and familiarity with the target language culture of the target text. The reduction even will not only vary from film to film, but also from scene to scene.

\section{2 Translation strategies in text reduction}

In order to achieve effective translation in synchronizing the spoken dialogues on the screen, subtitle translators have to do some translation strategies to comply with text reduction requirement as previously mentioned. Here are what Antonini (2005: 213-214) means by each of the strategies: 


\subsubsection{Elimination.}

It deals with cutting out elements which has no effect to change the original meaning of ST (Antonini, 2005: 213-214). This strategy, which is sometimes called omission or deletion, is considered "unavoidable" (Cintas \& Remael, 2007: 162). The strategy works by modifying the forms only, not the contents. In other words, subtitle translators must distinguish which elements or parts are essential and which can be omitted. Matielo (2011, p. 39) posits that the aspects omitable in this particular strategy are as follows: hesitations, false starts, unfinished sentences, redundancies, things or ideas understood visually, and formulaic expressions (Cintas \& Remael, 2007: 165). Elimination strategy can be applied in the sample of removing "Yes, I agree with you" on the screen while the actor was nodding his head in the visualization.

\subsubsection{Rendering.}

It is often known as an act of changing (mostly done by eliminating) some features (Antonini, 2005: 213-214). Among the eliminable features include the form of dialect, taboo language, and slang. "Shut your fucking mouth up!" will be commonly translated by AV translator into "Tutup mulutmu!" in Indonesian language which literally means 'please close your mouth!'.

\subsubsection{Condensation.}

The last of the three strategies proposed by Antonini (2005: 213-214) is called condensation. It deals with the simplification and fragmentation (changing the syntactic features). The strategy will produce a more reader-friendly text for viewers by doing reformulation of syntactical feature of ST. The translation, therefore, will not be done in a wordby-word method as it in essentially meant to convey maximum information yet using minimum linguistic means (Cintas \& Remael, 2007). AV translators will render the syntactical feature of ST into TL (of which differs from one to another). An AV translator will have to tend to translate "Take the time to talk a minute" into "Mari bicara sebentar" rather than "Sediakan waktumu untuk bicara sebentar" in Indonesian Language. In a more detailed outlook, condensation can be applied through following strategies (Table 1) (Cintas \& Remael, 2007: 150-159). They have made use of the strategies for translating France and Dutch as ST into English as TT in a movie subtitle.

Table 1: Strategies used in condensation strategy

\begin{tabular}{|l|l|}
\hline \multicolumn{1}{|c|}{ Strategy } & \multicolumn{1}{c|}{ Example } \\
\hline $\begin{array}{l}\text { Simplification of } \\
\text { verbal phrases }\end{array}$ & $\begin{array}{l}\text { ST in English: I should really be going actually. } \\
\text { TT: I have to leave. }\end{array}$ \\
\hline $\begin{array}{l}\text { Generalization of } \\
\text { words }\end{array}$ & $\begin{array}{l}\text { ST in English: You lied to us, son. Your own mother and father. } \\
\text { TT: You lied to us, your parents. }\end{array}$ \\
\hline $\begin{array}{l}\text { Change of word } \\
\text { classes }\end{array}$ & $\begin{array}{l}\text { ST in English: I was in a deep sleep. } \\
\text { TT: I slept soundly. }\end{array}$ \\
\hline $\begin{array}{l}\text { Refraction of a } \\
\text { compound sentence } \\
\text { into simple sentences }\end{array}$ & $\begin{array}{l}\text { ST in English: I didn't tell you just 'cause I thought you'd get pissed } \\
\text { off. } \\
\text { TT: I didn't say anything. I thought you'd be pissed off. }\end{array}$ \\
\hline $\begin{array}{l}\text { Change of active or } \\
\text { passive sentences }\end{array}$ & $\begin{array}{l}\text { ST in English: We knew that was where our heroes were kept. } \\
\text { TT: We knew that our heroes were there. }\end{array}$ \\
\hline
\end{tabular}

\section{Methodology}

The objects of study in this research are written documents, i.e. movie scripts and subtitle transcripts. The subtitles were taken from the two investigated movies. An interview was also made with an experienced subtitle translator (a 38-year old translator) who has been dealing with subtitle translation since 2004. This research relied on two data sources. The first data source was movie scripts from the Inside Out movie (Docter \& Carmen, 2015b) and Dirty Grandpa movie (Springfield, 2016), subtitle transcripts of Dirty Grandpa (Tj, n.d.) and Inside Out (Aorion, n.d.) movies. The other data source was the interview transcript. 
After collecting the data, the researcher compared the movie transcripts with the Indonesian subtitles. Then, on the basis of the principles of text reduction strategies proposed by Antonini (2005: 213-214), the researcher looked into the data in sound detail on how elimination, rendering, and condensation strategies were applied. The next step, the researcher categorized the data to make effective analyses. The researcher used the codes shown in Table 2, following Saldana (2009).

Table 2: The Classification Codes of Text Reduction Strategy

\begin{tabular}{|c|c|c|c|}
\hline \multicolumn{2}{|r|}{ Classification } & \multicolumn{2}{|c|}{ Code } \\
\hline \multirow{6}{*}{ Elimination } & Hesitation & \multirow[t]{6}{*}{$\mathrm{E}$} & $\mathrm{H}$ \\
\hline & False start & & $\mathrm{S}$ \\
\hline & Unfinished sentence & & $\mathrm{U}$ \\
\hline & Redundancy & & $\mathrm{R}$ \\
\hline & Visually understood information & & $\mathrm{V}$ \\
\hline & Formulaic expression & & $\mathrm{F}$ \\
\hline \multicolumn{2}{|l|}{ Rendering } & \multicolumn{2}{|l|}{$\mathrm{R}$} \\
\hline \multirow[t]{5}{*}{ Condensation } & Simplification of verbal phrases & \multirow[t]{5}{*}{$\mathrm{C}$} & VP \\
\hline & Generalization of words & & GW \\
\hline & Change of word classes & & WC \\
\hline & Refraction of compound sentence into simple sentences & & $\mathrm{CS}$ \\
\hline & Change of active or passive sentences & & AP \\
\hline
\end{tabular}

After giving codes to categorize the data, the researcher counted the frequency of elimination, rendering, and condensation strategies used before presenting the results on a table. Based on the frequency, the researcher was able to interpret which reduction strategies used in subtitle translation. The next stage was a descriptive analysis of the prominent cases. The very final stage was a close look at the interview transcript depicting interviewee's reasons for applying elimination, rendering, and condensation strategies in translating subtitles. The interview results were expected to triangulate the previous analysis which is to comprehend research data from another point of view (Moleong, 2002).

\section{Results}

\subsection{Strategies deployed in Dirty Grandpa and Inside Out subtitles}

As can be seen on Table 3 below, there were 209 data of subtitle translation containing strategies proposed by Antonini (2005). The following table is the frequency and percentage of the strategies used in Dirty Grandpa and Inside Out movies.

Table 3: Distribution of strategies

\begin{tabular}{|l|c|c|c|c|c|c|}
\hline \multirow{2}{*}{ Strategy } & \multicolumn{2}{|c|}{ Dirty Grandpa } & \multicolumn{2}{c|}{ Inside Out } & \multicolumn{2}{c|}{$\begin{array}{c}\text { Combined (Grandpa\& Inside } \\
\text { Out) }\end{array}$} \\
\cline { 2 - 7 } & $\mathbf{F r}$. & $\mathbf{\%}$ & $\mathbf{F r}$. & $\mathbf{\%}$ & Fr. & $\mathbf{\%}$ \\
\hline Elimination & 19 & 17.27 & 68 & 68.69 & 87 & 41.63 \\
\hline Rendering & 79 & 71.82 & 4 & 4.04 & 83 & 39.71 \\
\hline Condensation & 12 & 10.91 & 27 & 27.27 & 39 & 18.66 \\
\hline Total & 110 & 100 & 99 & 100 & 209 & 100 \\
\hline
\end{tabular}

Translators applied the three strategies (elimination, rendering, and condensation) in translating spoken English into written Indonesian language. However, the frequency of the use of translation strategies differ one to another. One strategy was applied more frequently than other strategies. In subtitling Dirty Grandpa, the subtitle translator used rendering strategy most frequently (79 times out of 110 occurrences). It amounts to 71.82 of the total percentage. It might suggest the variety of genre which influences dialogue topics. Dirty Grandpa contributed 
more in rendering strategy as the movie targeted adult audiences with common taboo expressions. The elimination strategy follows subsequently $17.27 \%$ of the frequency. The least strategy used was condensation strategy which only involved $10.91 \%$ frequency case.

Unlike the previous data, elimination strategy ranked the highest in Inside Out movie which was 87 cases or $41.63 \%$ of the total frequency. It is followed by rendering strategy with a slight difference that is 83 cases. While, condensation is used one which only in 39 cases. This means that the subtitle translators of the two movies were prone to use elimination strategy as proven by the total frequency of $41.63 \%$ in all cases combined. Rendering strategy made up of $39.71 \%$ of the whole adopted strategy. Condensation strategy was the least frequently used strategies which only amounts to $18.66 \%$ of all the 209 data found.

\subsection{Elimination strategy}

As mentioned before, elimination strategy was proven the predominant strategy used in both movies, 68 cases in Inside Out and 19 cases in Dirty Grandpa. As can be further detailed, it was applied through omitting information of hesitations $(\mathrm{H})$, false starts $(\mathrm{S})$, unfinished sentences $(\mathrm{U})$, redundancies $(\mathrm{R})$, information which can be understood visually $(\mathrm{V})$, and formulaic expressions $(\mathrm{F})$.

Below are some excerpts were made available to contextualize the cases:

\section{a. Data Dirty Grandpa E.7}

English version : She just gets, like, anxious.

Indonesian version : Dia cuma merasa cemas.

The scene was displaying Jason and his grandpa conversing about the phone call from Meredith - Jason's fiancée. Knowing the fact that Grandpa did not really like Meredith, Jason tried to defend his fiancée by replying Grandpa's utterance. However, at that time, he might not feel sure and just try to find any defensive word so it resulted in a word 'like' in the pause time of thinking, signing his hesitation. Spotting a hesitation case, the translator omitted the word 'like' to minimize words written in the subtitle. Rather than providing a longer translation 'Dia cuma merasa, seperti, cemas', she/he simply translates 'She just gets anxious' into 'Dia cuma merasa cemas'.

\section{b. Data Dirty Grandpa E.2}

English : What, do you listen to NPR in your Volvo?

Indonesian : Apakah kamu mendengarkan NPR di Volvo kamu?

Nick, Jason's cousin, was offended by Jason's utterance. In a high tension, Nick then replied Jason. The sentence was 'What, do you listen to NPR in your Volvo?'. He did a false start, probably as a result of his madness. He first wanted to say 'what' but then he stopped, quickly changed his mind, and had to start again to correct the sentence he was actually going to say - which was 'Do you listen to NPR in your Volvo?'.

The occurrence of false start benefitted the subtitle translator in giving him a chance to eliminate the word ' $w$ hat' - considered as false start. As a result, the subtitle made is 'Apakah kamu mendengarkan NPR di Volvo kamu' by eliminating the word 'what'. The case sample is line with Matielo's theory reducation can be done by eliminating false start.

\section{c. Data Inside Out E.1}

\section{English $\quad$ : Can I just... If you could... I just want to fix that. \\ Indonesian : Bisakah aku ... biar kuperbaiki itu.}

Elimination strategy can take its action in deleting unfinished sentences. The above dialogue is an example of subtitle translator's action in eliminating unfinished sentence. In the scene, Joy was trying to take control of the button and to persuade Sadness not to intervene with the button. Joy was trying to ask if she could fix the button; however, she gave some pause probably in order to offer alternative 'If you could' - it might turn Sadness to be subject instead of Joy herself. She changed her mind, and by not finishing her sentence 'If you could', Joy continued to put herself in the center of the next sentence 'I just want to fix that'. The translator used this to limit the space by deleting the unfinished sentence 'If you could'. 


\title{
d. Data Inside Out E.8
}

\author{
English : Great. This is just great. \\ Indonesian : Bagus.
}

Fear did not really like the new house Joy would live in. He sarcastically commented

'Great. This is just great'. The utterance 'great' was repeated by Fear in another sentence of 'This is just great'. The translator did not pay much attention to the repetition Fear had made, he simply ignored the phrase of 'This is just great' and went on translating 'Great. This is just great' into 'Bagus'. This sample represents the deletion of redundancies in elimination strategy.

\section{e. Data Inside Out E.32}

\author{
English : No, no, no. \\ Indonesian : - (shaking head)
}

Joy, in the scene, was trying to convince that the plan would not fail. She replied to Sadness' hesitation by persistently saying 'No, no, no' while shaking her head. Translator found a momentum for a word deletion in the dialogue to offer a blank screen for a second. It appeared in the additional visual information of Joy's head shaking which could substitute the words 'No, no, no'. It is in line with the idea that elimination strategy can be done by omitting information which can be understood visually.

\section{f. Data Inside Out E.30}

English : You know what? Save Chopsticks and Heart and Soul. Indonesian : Simpan Chopstick dan Heart dan Soul.

Cintas and Remael's feud about the elimination of formulaic expression was confirmed through observing the above dialogue. The researcher considered the sentence 'You know what' as a formulaic expression. The expression is fixed in form and used together contextually. 'You know what?' (Tahukah kamu) - sentence was not included in the translation because the sentence was formulaic expression which did not need to be understood as the content information of the dialogue. The translator deleted the formulaic expression as an elimination strategy by simply translating the sentence 'Save Chopsticks and Heart and Soul'.

\subsection{Rendering strategy}

Another translation strategy proposed by Antonini (2005) is rendering strategy. It was proved from the collected data, presented in the Table 3 above, that rendering strategy was applied through eliminating the feature of taboo words. When it comes to total, rendering strategy stood the second rank with the occurrence of 83 sentences rendered. Even so, rendering strategy did not have a fixed position. Rendering strategy amounted to $71.82 \%$ of cases in subtitling Dirty Grandpa movie, in contrast to only $4.04 \%$ cases in Inside Out.

It can be inferred that the use of rendering strategy really depends on the dialogue topic of the movie. When it comes to an adult movie $(18+$ movie $)$, the movie dialogue tended to contain taboo words as common expressions. Unlike all age movie which generally contain limited number of taboo materials, rendering strategy might be among the most relevant. In adult movies.

The following instance provides a dialogue which had been rendered to fit the Dirty Grandpa subtitle.

Data Dirty Grandpa R.11

English : The fucking piece of shit car never starts!

Indonesian : : Mobil rongsokan ini tidak pernah mau menyala.

Shadia's friend who was in a hurry trying to start the car which unfortunately fails. He got pissed off and swore at the car in the sentence 'The fucking piece of shit car never starts'. The translator translated the sentence into 'Mobil rongsokan ini tidak pernah mau menyala'.

She/he simply rendered the phrase which was considered taboo 'the fucking piece of shit' into 'rongsokan'. The adjective of 'rongsokan' meaning 'useless' was put to substitute the taboo words in order to both produce less character in the subtitle and to express politeness (down-tone the taboo words). 


\subsection{Condensation strategy in Dirty Grandpa and Inside Out subtitles}

Condensation strategy dealt with the simplification and fragmentation of words and sentences. There were 39 data (18.66\%) reformulation of English syntactical feature made by the translators. The researcher found that condensation strategy (C) was used through simplification of verbal phrases (VP), generalization of words $(\mathrm{GW})$, change of word classes (WC), refraction of compound sentence into simple sentences (CS), and change of active or passive sentences (AP).

Below are some samples provided for reference:

\section{a. Data Dirty Grandpa C.12}

English $\quad:$ I think I'm going to have to fight them all.

Indonesian : Kukira aku harus melawan mereka semua.

The clause 'I'm going to have to fight' was supposed to be translated into 'Aku akan harus melawan'. However, the subtitle translator took an action of condensation strategy which was done through simplification of verbal phrases. The phrase 'am going to' was not included in the subtitle translation because the translator intended to simplify it by keeping only the translation of the verb 'have to' - meaning 'harus'. It was even better to simplified since Indonesian Language does not have such a complex phrases equivalence.

\section{b. Data Inside Out C.1}

\section{English : She's good, we're good. It's all great \\ Indonesian : Kami baik saja. Semuanya baik saja.}

In the scene, Joy was telling the audience that Riley was in a good condition, so were Joy and her friends, by uttering 'She's good, we're good. It's all great!'. Having the intention of minimizing words but maximizing information, condensation strategy was applied by generalizing word meaning. The translation kept the intention of telling the audience that Riley, Joy and friends were in a good condition by condensing the pronouns 'she' and 'we' into 'kami' (meaning ' we'). By stating only 'we', the audience would still convey the information that the subjects being discussed were all inclusive.

\section{c. Data Inside Out C.4}

\section{English : It would be a big help. \\ Indonesian : : Akan sangat membantu.}

A change of word classes, in fact, would also help translator to effectively translate the English spoken text into the written Indonesian. By changing the word class, the translator simply condensed the word formation. The noun phrase of 'a big help' was hanged from a noun into an adjective. The translator picked the adjective 'helpful' to help translate the English version into 'sangat membantu'.

\section{d. Data Dirty Grandpa C.8}

English $\quad$ : Which is why I don't understand how we got so far off schedule.

Indonesian $\quad$ : Di mana aku tidak mengerti kenapa kita terlambat dari jadwal.

The literal translation for 'Which is why I don't understand how we got so far off schedule' was supposed to be 'Hal inilah yang membuatku tidak paham bagaimana kita bisa sangat terlambat jadwal'. However, the translator initiated the refraction of a compound sentence into a simple sentence for the above dialogue. It contained three syntactical chunks that could be simplified into a shorter sentence containing only two chunks 'Aku tidak mengerti, kenapa kita terlambat dari jadwal' - which means 'I don't understand, why we got so late'.

\section{e. Data Inside Out C.10}

English $\quad:$ Of course! It runs on song power.

Indonesian $\quad$ : Tentu saja, ditenagai oleh lagu.

Bing Bong, Riley's imaginary friend, promoted his rocket which will work if the passengers sing a song to Joy. He said 'It runs on song power'. In the attempt to condense the sentence but producing maximum information, a change from active sentence to passive sentence was made. 'Roket ini bekerja dengan tenaga lagu' was condensed into 'ditenagai oleh 
lagu' without changing the original meaning but substantially minimizing the characters in the screen that it altogether facilitates readership for audiences.

\subsection{Interview with the subtitle translator}

Having done the analysis of the subtitle translation, an interview was conducted. The following is the finding to substantiate the previous analysis.

a. Subtitle translation is produced by both official and unofficial subtitle publishing companies. The official publishing company, such as iflix, usually has its own standard in deciding the maximum characters provided in the movie screen. It, however, issues specific regulations in doing subtitle translation, such the use of alphabets instead of numbers in translating the speaker's utterance of number. An unofficial publisher, conversely, identifiable through $S R T$ file, has its freedom in deciding the standards of subtitling.

b. As a subtitle translator, he applies some translation strategies in order to produce effective translation. He admits to use all three strategies, elimination to eliminate unimportant, rendering to substitute taboo words or swear words with a more acceptable words, simplification to condense the words and their syntactical forms to minimize the space used in the screen. People can simplify verbal phrases although it is often not recommended to change active sentence into passive sentence or reversed. In addition, he added that he usually 'makes up' words in applying rendering and simplification strategy. To do so, he usually looks for equivalent words having the closest possible meanings.

c. As for the translator's reasons for applying the three strategies: first, is to meet the standard of subtitles which is regulated by the subtitle publishing company such as character and space limitation; second, is to respect cultural differences done through common sense consideration which often helps to decide whether deleting, substituting, or simplifying; third, the need to be well aware of the syntactical differences between English and Indonesian as the former has more complex grammatical features than the later. For the last case, the translators had to either simplify the English grammatical features or find Indonesian shorter words for substitution.

\section{Discussion}

Looking into the findings from movie transcripts and subtitle transcripts, the researcher summed them up in the following discussion. The researcher found that translators used the three strategies (elimination, rendering, and condensation) in translating Dirty Grandpa and Inside Out movies. Elimination strategy stands at the first rank. Rendering occurred very frequently (71.82\%) in Dirty Grandpa subtitle because the translator rendered and eliminated a lot of swear words in the movie; in contrast, the animation movie Inside Out rendering strategy occurred only $4.04 \%$. The occurrence of swear words was significantly different because Dirty Grandpa had the adults as its target audience; while Inside Out had the target audience of all age, especially kids. The case of condensation strategy was used almost similarly in the two movies, subsequently $10.91 \%$ and $27.27 \%$. Factors, other than genres, influencing the use of translation strategy use are the length of movies (102 minutes compared with 95 minutes) and translators' language style difference.

This study also finds that elimination strategy was applied through deleting information as a result of hesitations, false starts, unfinished sentences, redundancies, formulaic expressions, and information which can be understood visually. The deletion was done either partly or fully. Rendering was applied through changing and eliminating taboo words or swear words. The subtitle translator of Dirty Grandpa, for instance, tended to exclude the swear words from the subtitle translation. While, condensation strategy was applied through simplification of verbal phrases, generalization of words, change of word classes, rephrasing a compound sentences into simpler sentences, and change of active or passive sentences. Condensation strategy modified almost all of the grammatical features of English - such as tenses, parts of speech - to adjust with Indonesian language.

Drawing from the interview, the reasons for translation strategies use are: (1) meeting the standard of character and space limitation regulated by subtitle publishing company, (2) 
respecting English-Indonesia culture difference, and (3) taking advantage of the ST and TT language features and vocabulary differences.

Finally, all in all, this study confirms Antonini's argument about the principle of text reduction in the investigated cases. Subtitle translators are always confronted by constraints of matching the text and the screen. This is why text reduction was eminent in the investigated subtitles which manifests through elimination, rendering, and condensation strategies. The strategies very much help the translators in minimizing the characters of the subtitles.

\section{Conclusion}

Having analyzed and interpreted the data of the original transcripts, subtitle transcripts, and interview transcripts, the researcher draws a conclusion that text reduction manifested through all three strategies proposed by Antonini's (2005), which overall shows affinity to Cintaz and Remael's (2007) previous study on the subtitle text reduction. The translators under study used elimination, rendering, and condensation strategies in the process of movie subtitle translation. Elimination strategy was applied through omitting information which does not change the content meaning such as hesitation, redundancy, false start, unfinished sentence, and formulaic expressions. Rendering strategy changes and eliminates taboo language; and condensation strategy simplifying the syntactical features of the source language. As vindicated by the interview results, translators were compelled to use translation strategies to produce effective translation, to meet the standard of the publishing companies.

\section{References}

Antonini, Rachele. 2005. The perception of subtitled humor in Italy. Humor. International Journal of Humor Research, 18(2), 209-225. Available at https://doi.org/10.1515/humr.2005.18.2.209

Bogucki, Lukasz. 2013. Lodz studies in language - areas and methods of audiovisual translation research. Peter Lang Edition.

Chiaro, Delia. 2007. Audiovisual Translation. Routledge Encyclopedia of Translation Studies, 1-30. Available at https://doi.org/10.1002/9781405198431.wbeal0061

Cintas, J. Dias. \& Remael, Al. 2007. Translation practices explained. Manchester: St. Jerome.

Cintaz, J. Dias. \& Remael, Aline. 2014. Audivisual translation: Subtitling. New York: Routledge Taylor and Francis Group.

Docter, Peter \& Carmen, D. Ronaldo. 2015a. Inside out. The United States: Pixar Animation Studios, Walt Disnney Pictures.

Inside out final script. Available at http://www.dailyscript.com/scripts/inside-outscreenplay.pdf

Strategies in subtitling English cartoons or animations, 128-135. Available at http://www.ijllalw.org/finalversion5311.pdf

Subtitling words or omitting worlds? systemic functional linguistics unveiling meanings translated out of the subtitles of the tv series heroes. Available at https://repositorio.ufsc.br/bitstream/handle/123456789/94929/294683.pdf?sequence=1

Mazer, Dan. 2016. Dirty Grandpa. The United States: Lionsgate, BillBlock Media, QED International.

Moleong, J. Lexy. 2002. Metodologi Penelitian Kualitatif. Bandung: PT. Remaja Rosdakarya.

The rotledge companion to translation strategies. New York: Routledge. Available at http://www.data.ulis.vnu.edu.vn/jspui/bitstream/123456789/2910/1/UTF8_0415396417Translation.pdf

Saldaña, J. 2009. An introduction to codes and coding. The coding manual for qualitative researchers, 3.

Dirty grandpa movie Available at http://www.springfieldspringfield.co.uk/movie_script.php?movie=dirty-grandpa

Dirty grandpa indonesian subtitle. Available at www.warungbioskop.com 